\title{
Светлана Витун
}

- Гродненский государственный университет

- e-mail: s.vitun@grsu.by

- ORCID: 0000-0002-2810-2557

\section{Дмитрий Денищик}

- Гродненский государственный университет

- e-mail: Denixhik_DA_19@student.grsu.by

- ORCID: 0000-0002-4561-1548

\section{ЖЕНСКОЕ ПРЕДПРИНИМАТЕЛЬСТВО В РЕСПУБЛИКЕ БЕЛАРУСЬ КАК ОСНОВА РАЗВИТИЯ МАЛОГО И СРЕДНЕГО ПРЕДПРИНИМАТЕЛЬСТВА}

WOMEN'S ENTREPRENEURSHIP IN THE REPUBLIC OF BELARUS

AS A BASIS FOR THE DEVELOPMENT OF SMALL AND MEDIUM-SIZED ENTERPRISES

\section{Abstract}

- Goal - the purpose of this article is to generalize theoretical approaches to determining the specifics of women's entrepreneurship, to form a portrait of a modern woman in business, to identify barriers to the development of women's entrepreneurship and ways of its development.

- Research methodology - in the main part, the analysis of economic sectors, which modern women prefer when choosing a field of activity, is carried out. A comparative analysis was carried out and the distinctive features of enterprises run by men and women were identified.

- Score/results - the positive experience of conducting women's business in Poland, which can be successfully used to improve and develop women's entrepreneurship in Belarus, is revealed. Options for improving the current situation, aimed at the development of women's entrepreneurship, are proposed.

- Originality/value - the article deals with the formation and development of women's business as a basis for the activation of small and medium-sized businesses in the Republic of Belarus. The features of the activities of enterprises run by women are revealed, and the strengths and weaknesses in their work are highlighted. 
| Key words: women's entrepreneurship, gender equality, programs to support women's entrepreneurship, financial literacy, training activities, credit resources, investment project.

\section{1. Введение}

Одной из целей устойчивого развития Республики Беларусь на период до 2030 года, зафиксированной в «Национальном плане действий по обеспечению гендерного равенства на 2017-2020 гг.», было названо обеспечение гендерного равенства и расширение прав и возможностей всех женщин [Nacionalnyj plan...]. В документе подчеркивается, что «прогресс государств по достижению всеобщего процветания и благополучия для всех напрямую будет зависеть от их целенаправленных усилий по дальнейшему продвижению фактического равенства мужчин и женщин во всех сферах жизнедеятельности общества». Программа поддержки предпринимательства, реализуемая в Республики Беларусь в основу своей деятельности ставит принцип «Никого не оставить в стороне» - в этой связи тема гендерного равенства напрямую связана с активностями программы, а подобные исследования помогают очертить круг существующих проблем и сосредоточить усилия по их решению.

Развитие женского предпринимательства является не только вопросом гендерного равенства, но и одним из факторов устойчивого экономического развития страны. Развитие женского бизнеса способствует экономическому росту стран, расширению возможностей для женщин, сокращению разрыва в уровне оплаты труда, а также диверсификации взглядов и появлению новых идей на рынке.

Присутствие женщин среди лиц, принимающих решения, оказывает положительное воздействие на уровень эффективности и инновационности, а также на рост прибыльности компании. По оценкам Всемирного Банка особая ценность женщин-предпринимателей состоит в том, что, в отличие от мужчин, женщины в большей степени нацелены на повышение качества жизни и уровня человеческого капитала не только своих детей, но и общества в целом.

В связи с этим последние десятилетия повышенный интерес и практическую значимость представляет изучение проблем развития малых и средних предприятий, организованных женщинами, и установление 
факторов, оказывающих влияние на становление и развитие женского предпринимательства в Республике Беларусь. В этих условиях особое внимание уделяется детализированному определению портрета современной женщины в бизнесе и определению основных движущих стимулов для ухода в бизнес.

Особенностям развития женского предпринимательства посвящены труды С.Д. Резника и С.Н. Макаровой, которые позволили провести анализ и выявить особенности функционирования женского предпринимательства на различных этапах и определить барьеры в его развитии.

\section{2. Основная часть}

В Республике Беларусь, как и во многих странах мира, понятие «бизнес» ассоциируется с представителями сильного пола и предполагает, что во главе любого бизнеса стоит мужчина. Однако в данной статье мы хотим разрушить стереотипы и показать, что бизнесом может руководить женщина. При этом нужно отметить, что в некоторых отраслях женщины достигают большего успеха, чем мужчины.

Еще в конце 90-х годов особое место в развитии малого и среднего бизнеса было отведено женщинам-предпринимателям. В последние годы проблема гендерного равенства приобретает все большую значимость. Традиционно сложилось представление, что женщина должна рожать детей, заниматься семьей и исполнять иные обязанности, но только не заниматься бизнесом. Как правило, женщины заняты на работах, которые малооплачиваемы, менее престижны, что соответственно порождает неуверенность женщин в собственных силах.

На протяжении последних лет роль женщины в общественной, экономической и политической жизни общества приобретает иной смысл. Современные женщины стали более амбициозны, инициативны, они стремятся быть независимыми, самодостаточными и востребованными. Это во многом обеспечивает им успешную деятельность. Эти позитивные тенденции являются результатом поэтапного совершенствования гендерной политики. Государство всегда уделяло этому особое внимание.

В существующей инфраструктуре поддержка женского предпринимательства находится на особом счету, отдельно реализуются проекты по организации женского бизнеса и созданию рабочих мест. 
Малое и среднее предпринимательство в Республике Беларусь проходит сложный путь. В то же время можно говорить, что женское предпринимательство в нашей стране имеет статус состоявшегося. Данное направление предпринимательства оценивается как одно из перспективных и динамично развивающихся в странах восточного региона стран Европы.

Вопрос развития женского предпринимательства и частного сектора в целом начинает получать все большую актуальность в Беларуси. Причиной этого являются поиск новых источников роста для белорусской экономики, одним из которых должен стать частный сектор. В женском предпринимательстве с одной стороны законы рыночной экономики действуют независимо и необратимо. С другой - государственное администрирование влияет на развитие предпринимательства. Проблемы, возникающие на пути развития предпринимательства в Республике Беларусь, особенно женского, внимательно изучаются и анализируются правительством страны.

В 2017 году был принят ряд нормативных актов по развитию частного бизнеса, которые нацелены на значимое упрощение условий для ведения бизнеса, а также снижение уровня государственного контроля над представителями частного сектора. Отдельно для такого сегмента как женское предпринимательство работают центры поддержки предпринимательства в регионах, внедрены и функционируют международные проекты в этом направлении. В качестве примера можно привести опыт Нарочанского края, где создано ОО «Женщины за возрождение Нарочанского края», которое реализует международный проект по развитию женского предпринимательства в сельской местности» [Proekt...]. На Гродненщине создано информационно-просветительское учреждение «Центр фермерских инициатив Гродненщины» под руководством Татьяны Чистяковой» [Linkedin].

В 2017 году кардинальные изменения претерпело законодательство о ремесленной деятельности, агроэкотуризме, самозанятости. Тем самым женщины получили возможность реализации своих навыков в данной сфере. В качестве положительного момента необходимо отметить либерализацию контрольной (надзорной) деятельности за предпринимателями.

Благоприятные условия для развития ремесленной деятельности, которые созданы в Беларуси, находят отражение в показателях устойчивого роста количества физических лиц, уплачивающих сбор за осуществление ремесленной деятельности. С 2005 года количество физических лиц, уплачивающих сбор за осуществление ремесленной деятельности, выросло в стране более чем в 100 раз [Ob osushchestvlenii...]. 
На 1 января 2018 года данный показатель составил 29381 человека, на 1 января 2019 - 36199 человек, на 1 января 2020 - 42660 человек [Ob osushchestvlenii...]. Таким образом, мы видим, что прирост за год составляет более 6 тыс. человек, что свидетельствует о значительном интересе физических лиц к данному виду деятельности.

Доля женщин-ремесленников, занятых ремесленной деятельностью, в общем количестве составляет 70\%, т. е. ремесленную деятельность можно с уверенностью назвать женским видом предпринимательства [Ob osushchestvlenii...]. В этой сфере деятельности женщина проявляет себя особенно ярко и широко. Она подтверждает предназначение женщины быть хозяйкой в доме и предоставляет ей неограниченные возможности в занятии таким направлением деятельности как агроэкотуризм.

Современный женский бизнес является разноплановым, следовательно можно провести анализ его деятельности по различным критериям.

B 2018 году компания SATIO, специализирующаяся на проведении социологических исследований и оказании консультационных услуг, провела опрос 410 респондентов. В число респондентов вошли собственники и люди, принимающие ключевые решения в бизнесе.

По данным опроса установлено, что около 30\% компаний принадлежат женщинам (таблица 1).

Таблица 1. Характеристика бизнеса по полу владельца в 2018 году

\begin{tabular}{l|c|c}
\hline Анализируемый показатель & $\begin{array}{c}\text { Женщина- } \\
\text {-собственник }\end{array}$ & $\begin{array}{c}\text { Мужчина- } \\
\text {-собственник }\end{array}$ \\
\hline Доля компаний в общем числе (\%) & 30,3 & 69,7 \\
\hline Рост продаж за последний год (\%) & 7,6 & 27,1 \\
\hline Рост продаж за последние три года (\%) & 18,4 & 36,1 \\
\hline Размер компании (число работников) & 10,6 & 17,3 \\
\hline Возраст компании (лет) & 8,8 & 10,2 \\
\hline Внедренные инновации (\%) & 33,3 & 38,9 \\
\hline Доля прибыли, приходящаяся на внедренные & 16,4 & 28,8 \\
инновации (\%) & & 2 \\
\hline
\end{tabular}

Источник: собственная разработка на основании: Issledovanie “Vse, chego... 
Данные, представленные в таблице 1 , показывают, что женский бизнес меньше по размеру, и в средней компании с женщиной-собственником занято 11 работников против 17 в компании с мужчиной-собственником. Женский бизнес более молодой и средний возраст в нем равен 8,8 годам, а возраст средней компании с мужчиной-владельцем составляет 10,2 лет. Одновременно женский бизнес отстает по динамике роста. Так, рост продаж за последний год в 4 раза меньше у женщины-собственника бизнеса, чем у компании со схожими характеристиками, где во главе стоит мужчина-собственник. По данным анализа за 3 последние года, уровень отставания составляет $100 \%$.

Инновационная активность незначительно меняется в зависимости от пола владельца бизнеса. Суть инновационной деятельности состоит в том, внедрила ли компания какие-либо радикальные либо сопутствующие новшества (продукт, услугу, новую стратегию) в течение последних 3 лет. Однако успешность реализации внедряемых инноваций проявляется в большей мере среди мужских бизнесов. Доля прибыли, приходящаяся на внедренные инновационные продукты, составила 28,8\% в мужском бизнесе и лишь $16,4 \%$ среди женского бизнеса.

Оценка личностных характеристик мужчин и женщин предпринимателей выявила ряд небольших различий (таблица 2).

Таблица 2. Гендерные различия в профиле владельца бизнеса в 2018 году

\begin{tabular}{l|c|c}
\hline Анализируемый показатель & $\begin{array}{c}\text { Женщина- } \\
\text {-собственник }\end{array}$ & $\begin{array}{c}\text { Мужчина- } \\
\text {-собственик }\end{array}$ \\
\hline Релевантный опыт работы (лет) & 14,70 \\
\hline Управленческий опыт (лет) & 9,00 & 12,80 \\
\hline Высшее образование (\%) & 96,20 \\
\hline Средний возраст & 91,30 & 42,40 \\
\hline Знание иностранных языков & 42,70 & 1,12 \\
\hline
\end{tabular}

Источник: собственная разработка на основании: Issledovanie: “Vse, chego...

Анализ гендерных различий в профиле владельца бизнеса свидетельствует о том, что женщины в бизнесе чуть более образованные, но у мужчин-собственников около 15 лет релевантного опыта и 13 лет опыта управления 
компанией - против 13 лет релевантного опыта и 9,7 управленческого у женщины-предпринимателя.

Наибольшая предпринимательская активность у женщин наблюдается в возрасте 25-54 лет, с пиком в возрасте 45-54 года, а далее идет спад. К этому моменту накапливается уже достаточное количество ограничений, отталкивающих людей от ведения собственного бизнеса и взятия на себя дополнительного риска. В качестве основных ограничений можно сформулировать следующие: наличие семьи, проблемы со здоровьем и иные личные причины. Однако, несмотря на присутствие большого количества ограничений, особенности рынка труда двигают женщин в сторону ведения бизнеса.

Секторальная разбивка компаний (таблица 3) показала, что женщины склонны выбирать сектор оптовой и розничной торговли, производство, гостиничный бизнес, а также сферу медицинских и социальных услуг. Наибольшее количество женщин-предпринимателей занято в торговле - 29\% и в производстве - 10,1\%. У мужчин-собственников наиболее популярны такие сферы деятельности, как торговля - 29,6\%, производство - 23,9\% и строительство - 18,9\%.

Таблица 3. Отраслевая разбивка по полу владельца бизнеса в 2018 году

\section{Анализируемый показатель}

\begin{tabular}{l|c|c}
\hline Торговля & 29,0 & 29,6 \\
\hline Промышленность & 10,1 & 23,9 \\
\hline Строительство & 7,3 & 18,9 \\
\hline Медицинские и социальные услуги & 8,7 & 1,3 \\
\hline Гостиничный и ресторанный бизнес & 8,7 & 2,5 \\
\hline Транспорт & 7,3 & 10,1 \\
\hline Иное & 29,0 & 13,8 \\
\hline
\end{tabular}

Источник: собственная разработка на основании: Issledovanie: “Vse, chego...

Одной их потенциальных причин различий в характеристиках и эффективности компаний под управлением мужчин и женщин является сегрегация. 
Это означает, что женщины сами выбирают менее производительные и прибыльные сектора, чтобы иметь большую гибкость в балансировании между выполнением различных социальных ролей. Поэтому стоит учитывать особенности каждой отрасли. Например, сфера услуг и торговля всегда были секторами, где уровень риска невозврата вложенных средств высок, а уровень доходности и инновационности низок.

Следовательно, вышеизложенное позволяет сделать вывод, что женский бизнес очень разнообразен и по ряду признаков значительно отстает от бизнесов, в которых собственником выступают мужчины. Тем не менее, необходимо отдать должное стремлению женщин войти в бизнес и их усердию в достижении поставленных целей.

Среди главных причин, по которым женщины приходят в бизнес, можно выделить следующие: стремление обрести финансовую независимость, желание воплотить бизнес-идею и возможность совмещать работу, семью и хобби. Кроме того, большинство бизнесвумен в стране мотивированы идеей быть независимыми в своем деле.

Главными сдерживающими факторами, по которым женщины не открывают свой бизнес, являются недостаток собственных средств и неуверенность в способности вести бизнес самостоятельно.

В целом женское предпринимательство рассматривается как позитивное экономическое явление, обеспечивающее открытие новых рабочих мест, а также привносящее в сферу бизнеса т. н. женский подход, характеризующийся повышенной ответственностью, низким рисковым поведением, осторожностью и легитимностью, гибкостью в управлении, честностью, стратегией на сохранение бизнеса, прозрачностью ведения дел, способностью находить нестандартные решения, повышенным стремлением к законопослушности, большей социальной ориентированностью.

В 2016 году в Минске состоялось официальное открытие программы «Женщины в бизнесе», инициированной Европейским банком реконструкции и развития (ЕБРР) и призванной помочь развитию белорусского женского частного предпринимательства. Программа реализуется в странах Восточного партнерства, включая, помимо Беларуси, такие страны, как: Армения, Азербайджан, Грузия Молдова и Украину. В целом она реализуется в 16 странах мира. Продолжительность данного проекта - 6 лет, с 2016 года по 2022. Программа «Женщины в бизнесе» является самой масштабной программой по поддержке женского предпринимательства в Республике Беларусь. Она финансируется ЕБРР, Европейским Союзом 
(EC), Швецией и Фондом поддержки стран с переходной экономикой на ранней стадии развития.

Швеция занимает очень активную позицию по вопросу гендерного равенства, что отражается в высокой степени участия шведок в общественной жизни и бизнесе. Так, в парламенте Швеции женщины представлены 47\%. Это является одной из главных причин, по которой Швеция принимает участие в данной программе. На реализацию программы в странах региона Восточного партнерства правительство Швеции выделило 47 млн шведских крон, что является эквивалентом примерно 5,2 млн евро.

Программа «Женщины в бизнесе» помогает малым и средним предприятиям, возглавляемым женщинами, получить доступ к финансированию и технологиям, необходимым для роста. Европейский банк реконструкции и развития обеспечивает доступ к финансовым ресурсам посредством займов от местных банков, предназначенных для развития малых и средних предприятий (МСП), которыми руководят женщины, а также организует бизнес-консультации для повышения конкурентоспособности данных компаний. Программа предусматривает тренинг, кураторство и поддержку с целью получения женщинами-предпринимателями возможности обмениваться опытом и знаниями с коллегами.

Целью данной программы является активизация предпринимательской деятельности женщин и обеспечение доступа к финансированию, а также в целом содействие участию женщин в коммерческой деятельности посредством предоставления финансовых средств и ноу-хау, необходимым для развития их бизнеса.

Программа реализуется по двум направлениям:

1) доступ к финансовым ресурсам: специальные кредиты для участвующих финансовых учреждений (УФУ) с целью последующего кредитования МСП, возглавляемых женщинами; размещение рисков, техническая поддержка для УФУ, внутренне развитие компетенций и потенциала, разработка новых продуктов, маркетинг и охват клиентов-женщин;

2) доступ к технологиям и знаниям: консультации по ведению бизнеса и коучинг, обучение ключевым предпринимательским навыкам, онлайн-инструмент для диагностики бизнеса Business Lens, кураторство, сетевые семинары.

В рамках данной программы ЕБРР осуществляет: бизнес-диагностику и выявление потребности в консалтинге; оказывает помощь в поиске 
консультантов; компенсирует 60\% расходов на консультационный проект, но не более 10 тыс. евро; дополнительно компенсирует 20\% стоимости консалтинга при получении кредита в банке-партнере по программе «Женщины в бизнесе»; делает оценку эффективности проекта.

Требования к компаниям-участникам:

- более 2 лет на рынке,

- более 50\% капитала компании принадлежит гражданам Республики Беларусь,

- численность от 10 до 250 сотрудников,

- годовая выручка не более 50 млн евро,

- безупречная деловая репутация и финансовая устойчивость.

Кроме того, для того, чтобы стать участником этой программы, общее оперативное руководство должно осуществляться женщиной. Что касается сферы деятельности, ЕБРР поддерживает ведение бизнеса практически во всех отраслях и секторах экономики. Программа предлагает возможности наставничества и налаживания связей, а также обучение и бизнес-консультации по вопросам операционной эффективности, стратегии, финансового управления и многое другое.

Европейский банк реконструкции и развития уже свыше 4 лет помогает малым и средним предприятиям. На сегодняшний день профинансирована деятельность более чем 150 белорусских компаний, оказана помощь в получении услуг местных консультантов либо привлечены международные отраслевые эксперты [EU4Business...].

Для финансирования кредитных инструментов и, частично, для программы наращивания потенциала со стороны партнерских финансовых учреждений инвестиционным фондом соседства ЕС выделены 4,5 млн евро. 900 тыс. евро предоставил Фонд поддержки стран с переходной экономикой на ранней стадии развития ЕБРР. Данная программа является глобальной программой развития женского предпринимательства, но кроме нее в Республике Беларусь имеется ряд национальных проектов, направленных на развитие женского предпринимательства.

Со стороны местных банков на данный момент проявили интерес к участию в программе в качестве финансовых посредников ОАО «Белинвестбанк» и ОАО «Белорусский народный банк». Банки готовы разработать специализированные банковские услуги для устойчивого финансирования предприятий, руководителями которых являются женщины. 
Наибольших успехов в направлении взаимодействия с женским предпринимательством в Республике Беларусь достиг ОАО «Белинвестбанк». Данный банк одним из первых кредитно-финансовых учреждений страны поставил перед собой задачу всестороннего содействия белорусским бизнес-леди. Он первым определил критерии отнесения клиентов к сегментам женского предпринимательства и разработал специальные пакеты расчетно-кассового обслуживания и кредитные продукты, что отсутствует в иных коммерческих банках Республики Беларусь.

Первым проектом, направленным на развитие женского бизнеса в стране, стал проект «Успешная Я»- совместная инициатива по развитию и поддержке женского предпринимательства ОАО «Белинвестбанк» и Европейского банка реконструкции и развития. Формат проекта - это проведение серии бизнес-встреч, на которых женщины-предприниматели узнают о финансовых и нефинансовых возможностях для улучшения собственного бизнеса.

Следующим, не менее значимым мероприятием, в котором ОАО «Белинвестбанк» принял участие, был Женский Саммит «Ты можешь». Первый такой Саммит прошел в марте 2019 года. Подобные саммиты проходили в каждом областном центре в формате бизнес-завтрака. Они собирали от 25 до 30 бизнес-леди, для обсуждения проблем развития женского предпринимательства. Проведение ОАО «Белинвестбанк» подобных мероприятий сформировало новое представление об этом финансовом институте. Об этом свидетельствует постоянный рост количества бизнес-леди, посетивших данные мероприятия.

В 2020 году ОАО «Белинвестбанк» выступил генеральным партнером самого масштабного мероприятия, посвященного женскому бизнесу, Global Women Forum. Данное мероприятие привлекло в себе свыше 4 тыс. женщин и позволило современным бизнес-леди наладить деловые отношения друг с другом, поделиться секретами ведения успешного бизнеса. Кроме консультационной и образовательной поддержки ОАО «Белинвестбанк» оказывает своим клиентам, в том числе и представителям женского предпринимательства, значительную финансовую поддержку.

С каждым годом работа в банке в этом направлении совершенствуется, и в качестве результата явилось создание в июне 2019 года Центра поддержки и развития женского предпринимательства (далее: Центр). В его состав вошли самые предприимчивые и целеустремленные женщины ОАО «Белинвестбанк», которые готовы изучать проблематику современного 
женского бизнеса и оказывать всестороннюю поддержку бизнес-леди. Основная задача Центра - стимулирование и поддержка женского предпринимательства, содействие в получении финансовых и технических ресурсов, информационных, методологических и консультационных услуг по организации и ведению бизнеса.

Особая роль ОАО «Белинвестбанк» в части женского предпринимательства состоит в формировании экосистемы взаимоотношений для стимулирования развития данного сегмента малого и среднего бизнеса, которая предполагает наличие и постоянное совершенствование банковских продуктов, ориентированных на женский бизнес.

По данным исследования «Index of Women Entrepreneurs», которое проводит Mastercard, в экономически благополучных государствах с развитыми традициями предпринимательства женщины встречаются в числе учредителей компаний чаще, чем в Республике Беларусь (31-35\%) [MIWE2018]. Женщины, владеющие бизнесом в странах с индустриальными рынками, могут воспользоваться большими возможностями и ресурсами, включая доступ к капиталу, финансовым сервисам и академическим образовательным программам, в отличие от предпринимательниц в странах с развивающейся экономикой.

В целом рейтинг стран по критерию условий для ведения бизнеса женщинами показывает, что начинающие и имеющие опыт женщины-предприниматели продолжают добиваться успеха во всем мире, несмотря на гендерные и культурные стереотипы, которые могут создавать существенные препятствия для продвижения их бизнеса.

В ноябре 2019 года Mastercard представила третью волну исследования «Mastercard Index of Women Entrepreneurs», в котором определен рейтинг стран, где бизнес, которым управляет женщина, может стать наиболее успешным. Топ-10 стран с наилучшими условиями и возможностями для женщин, которые хотят преуспеть в бизнесе приведен в таблице 4. Результаты исследования подтвердили, что женщины продолжают успешно развивать бизнес и имеют более высокий уровень участия в деловых процессах на открытых и динамичных рынках с высокими показателями поддержки малого и среднего бизнеса и легкости ведения бизнеса. Они могут также использовать вспомогательные ресурсы, включая доступ к капиталу, финансовым услугам и академическим образовательным программам. 
Проанализировав показатели таблицы 4, необходимо отметить присутствие в данной рейтинге стран с наилучшими условиями и возможностями для ведения женского бизнеса на 10-м месте - Польши, которая соседствует с Республикой Беларусь.

Таблица 4. Топ-10 стран с наилучшими условиями и возможностями для ведения женского бизнеса за 2019 года

\begin{tabular}{c|cc} 
Место & Страна ведения бизнеса & $\begin{array}{r}\text { Уровень доступност бизеса } \\
\text { для женщин (\%) }\end{array}$ \\
\hline 1 & США & 70,3 \\
\hline 2 & Новая Зеландия & 71,2 \\
\hline 3 & Канада & 69,0 \\
\hline 4 & Израиль & 68,4 \\
\hline 5 & Ирландия & 67,7 \\
\hline 6 & Тайвань & 66,2 \\
\hline 7 & Швейцария & 65,8 \\
\hline 9 & Сингапур & 65,6 \\
\hline
\end{tabular}

Источник: собственная разработка на основании: Predstavitelstvo obshchestvennogo...

Из стран бывшего социалистического лагеря в деле перехода к рыночной экономике Польша была одной из первых стран. Начался этот процесс в 1989 году. Проведя в стране ряд радикальных и либеральных реформ, экономисты и политики получили в итоге значительные результаты. Основная идея, которая лежала в их основе - разумное вытеснение государства из реального экономического сектора. Ставки были сделаны на развитие малого и среднего бизнеса. Принятые законы о либерализации экономики послужили толчком для развития частного сектора. Первая программа поддержки малого и среднего бизнеса в стране появилась в 1995 году. Очень быстро именно эта форма ведения бизнеса стала основой структуры 
экономики Польши, а малый бизнес сумел проникнуть в отрасли промышленного производства.

В Польше для женщин-предпринимателей минимизированы административные процедуры и нагрузки, доступны источники финансирования, существуют мягкая и упрощенная системы налогообложения.

Вступление Польши в 2004 году в Евросоюз позволило ей стать участником многих европейских социальных и экономических программ. В течение 3 лет был принят ряд законов для определения рамок женского предпринимательства. Характерной чертой женского бизнеса Польши является наличие большого количества микропредприятий с небольшой численностью работников. Производства, как правило, размещены в частном секторе на собственных площадях, что позволяет экономить на аренде. Ряд женских бизнесов Польши возникли из традиционных занятий практически каждой женщин - приготовления еды, уборки, вышивания. Примерами реализации данных традиционных женских занятий служат большое количество ресторанов и кафе, кулинарных школ, швейных ателье, возглавляемых женщинами-предпринимателями.

На данный момент в Польше женщин-предпринимателей только одна треть (около 35\%) от общей массы участников малого и среднего бизнеса, а в крупных компаниях ситуация еще хуже - там работают исключительно мужчины [Respublikanskaya...].

Сейчас под женским бизнесом в Польше понимается бизнес, где в составе учредителей ведущую роль играет женщина. Среди учредителей крупных компаний в Польше численность женщин очень мала. Превалирует мнение, что женщины не способны принимать быстрые решения - ведь они настроены на сотрудничество, а не на конфликт. Однако это неверно, так как стремление к ситуации win-win, когда выигрывает каждая из сторон, благоприятно сказывается на любом виде бизнеса. Такую черту можно отнести к преимуществу женского бизнеса, а не ее недостатком.

В Польше $62 \%$ женщин считают, что стоит иметь свой бизнес, так как это приносит более высокие доходы и социальное обеспечение, позволяет развиваться профессионально и самореализоваться. Некоторых женщин в бизнес притягивает врожденное чувство независимости [Respublikanskaya...].

Вести свой бизнес в силу многих факторов способен далеко не каждый индивид, и исследования, проводимые в мире, это подтверждают. Из всех основанных фирм только 5\% добиваются успеха и выживают. Остальные 95\% 
не выдерживают конкуренции и закрываются, нанося колоссальный удар по финансовым средствам и самолюбию польских женщин-предпринимателей.

Польским женщинам, как и белорускам, начать свой бизнес мешает чувство неуверенности в себе, отсутствие поддержки близких, а также отсутствие необходимых знаний и бизнес идей, хотя оригинальные идеи лежат в основе только 1\% фирм [Respublikanskaya...]. Залог успеха остальных компаний - это ежедневная, регулярная, напряженная работа. Главное не идея, а ее исполнение, потому что даже самая гениальная идея может потерпеть экономический крах в связи с плохим исполнением.

В Польше, как и в Республике Беларусь, проводятся различного рода мероприятия для женщин-предпринимателей, а также ведут работу различные фонды и организации, которые содействуют созданию и развитию женского предпринимательства.

Так, в Варшаве, при содействии Фонда предпринимательства женщин PARP (Польское агентство по развитию предпринимательства), ведется поддержка женского предпринимательства в рамках авторской программы под названием «Сеть предприимчивых женщин» (SPK) и «Бизнес в женских руках». Финансирует эти проекты фонд United Way Worldwide (Нью-Йорк).

Программа поддержки рассчитана на 6 месяцев. В ней принимают участие 60 женщин, которые имеют бизнес-идею, мотивированы основать свою собственную фирму, креативны, ориентированы на успех, хотят работать. Кроме того, участницы должны быть готовы принимать активное участие во всех элементах программы. Это встречи нетворкинг (в кругу участниц для знакомства, завязывания контактов и совместной работы) и be the change (встречи с участницами сети предприимчивых женщин), курсы и мастер-классы, SkillShare (10-дневные курсы для начинающих бизнес), совместная работа с куратором и встречи с ним оne to one по одной в месяц. Все вместе взятое помогает участницам доработать бизнес-идею, получить для ведения бизнеса нужные знания и помощь, почувствовать поддержку и выступить в СМИ со своей программой и историей, т. е. бесплатно прорекламировать свое будущее дело. Практика Польши показала, что при такой поддержке из 100 человек 73 в итоге открывают свое дело [Respublikanskaya...].

Женское предпринимательство в Польше ориентировано на освоение и использование современных технологий и возможностей, которые предлагает глобальный рынок, так как будущее за автоматизацией.

Подводя итог, надо отметить, что в Республике Беларусь больше женщин, желающих заниматься бизнесом, чем в Польше. Объясняется это не 
только тем, что многие их них нацелены на достижение своей мечты - создания собственного дела. Причиной является также и наличие безвыходной ситуации на определенном этапе жизни (потеря работы и отсутствие средств для существования), что является хорошим мотиватором. В свою очередь, польские женщины могут позволить себе заниматься любимым делом ради удовольствия, так как они достаточно экономически обеспеченны. Принципы развития польского женского предпринимательства аналогичны белорусским: в стране необходимо проводить различного рода обучающие мероприятия, бизнес-встречи для знакомства женщин-предпринимательниц Польши и Беларуси, мастер-классы для начинающих и уже состоявшихся бизнес-леди.

Дальнейшее развитие женского предпринимательства в Республике Беларусь тесно переплетается с развитием женского предпринимательства в Польше, что особенно актуально в условиях развития трансграничного сотрудничества. Опыт, который накоплен в Польше в области развития женского предпринимательства, в дальнейшем будет апробирован и предложен для использования женщинам из числа предпринимателей в Республике Беларусь.

Положительной чертой польского женского предпринимательства, которую необходимо взять белорусским женщинам-предпринимателям на заметку, это организация бизнеса по месту жительства, что минимизирует затраты на аренду и повысит эффективность ведения бизнеса.

\section{3. Заключение}

Анализ представленных материалов свидетельствует о присутствии женского предпринимательства в Республике Беларусь на достаточно высоком уровне. Доля женского предпринимательства в Республике Беларусь балансирует на уровне 30\%. Для сравнения, в соседней Польше он составляет $35 \%$, при чем следует подчеркнуть, что в этой стране развитие женского предпринимательства насчитывает свыше 30 лет.

При этом, существует множество факторов - как со стороны государства, так и коммерческих банков - которые оказывают негативное влияние на развитие данного сегмента малого и среднего бизнеса в Республике Беларусь. Среди них можно выделить: государственное регулирование, наличие административных барьеров, жесткую налоговую систему, эле- 
менты коррупции, недобросовестную конкуренцию, затрудненный доступ к бизнес-образованию, проблемы в карьере на время декретного отпуска, боязнь рисков, низкую распространенность технического образования.

Кроме того, можно выделить «чисто женские ограничения», которые присущи значительному числу женщин-предпринимательниц и снижают эффективность управления фирмой: мягкость характера, трудность санкционирования за ошибки, долгое переживание событий, эмоциональность, сниженный потенциал риска, отсутствие авантюризма, повышенная ответственность, недостаток амбициозности.

Однако наличие этих проблемных моментов не значит, что женские опасения носят отрицательный характер и ведут к неудачам в бизнесе. Наоборот, по мере того, как женский бизнес набирает силу, финансовые учреждения и партнеры убеждаются в том, что женщины очень ответственны по своим финансовым и партнерским обязательствам. Женщины показывают гибкость в бизнесе, они становятся хорошими менеджерами, быстро привыкают преодолевать трудности, понимать механизм работы рынка, особенно потребительского.

Белорусские женщины-предпринимательницы имеют высокий внутренний потенциал для продолжения и развития предпринимательской деятельности. Предпринимательская и общественная деятельность женщин указывает на наличие разнообразных ресурсов, которые могут положительно влиять как на развитие экономических, так и политических процессов в белорусском обществе. Эффективность и темпы формирования рыночной экономики в Республике Беларусь в значительной степени зависят от вовлеченности женщин в этот процесс.

Развитие женского предпринимательства нуждается в целенаправленных действиях и реализации специальных программ, которые направлены как на преодоление объективных сдерживающих факторов, так и субъективных.

В первую очередь это должны быть общие меры, направленные на создание благоприятного климата предпринимательства, создание простых и доступных механизмов, позволяющих получить инициативным женщинам необходимые знания и стартовые возможности для создания собственного бизнеса. Необходимы специальные меры для обеспечения доступа женщин к кредитам и займам, объектам приватизации. Учитывая постоянный большой спрос на образовательные и консультационные услуги, необходимо содействовать созданию постоянно действующей системы обучения 
и консультирования. Растущая конкуренция требует обеспечения доступа женщин к новым технологиям, обучения работе в сети Интернет.

Для расширения женского предпринимательства необходимо создать благоприятные условия в местных сообществах через развитие социального партнерства между органами власти и предпринимательскими структурами. Необходимы меры по развитию женской предпринимательской сети, которая со временем должна стать группой лоббирования и защиты интересов женщин-предпринимательниц.

Для преодоления субъективных факторов, сдерживающих деловую активность женщин, необходимо - с помощью средств массовой информации - формировать позитивный имидж женского предпринимательства, создавать социальные и психологические программы поддержки женщин-предпринимательниц.

\section{| Литература}

“Delo. Gosudarstvennyj bizness-zhurnal” || «Дело. Государственный бизнесс-журнал», [электронный ресурс] https://delo.by/articles/news/economy/women-y-rylja [дата доступа 10.06.2020].

Est li raznica mezhdu muzhskim $i$ zhenskim biznesom? V kakikh sferakh udaecya zarabotat i chem prikhodicya zhertvovat, "Ekonomicheskaya gazeta", 6.03.2020 || Есть ли разница между мужским и женским бизнесом? В каких сферах удается заработать и чем приходится жертвовать, «Экономическая газета», 6.03.2020, [электронный ресурс] https://neg.by/novosti/otkrytj/est-li-raznica-mezhdumuzhskim-i-zhenskim-biznesom [дата доступа: 11.06.2020].

EU4Business - Programma EBRR “Zhenshchiny v biznese” v stranakh Vostochnogo partnerstva || EU4Business - Программа ЕБРР «Женщины в бизнесе» в странах Восточного партнерства, [электронный ресурс] https://eu4business.eu/ru/ programme/zhenshchiny-v-biznese [дата доступа: 11.06.2020].

Good Start. Putevoditel predprinimatelya || Good Start. Путеводитель предпринимателя, [электронный ресурс] https://goodstart.by/arts/7-proektov-dlja-podderzhki-zhenskogo-predprinimatelstva-v-belarusiд [дата доступа: 10.06.2020].

Issledovanie: "Vse, chego vy ne znali o zhenshchinakh v belorusskom biznese" || Исследование: «Все, чего вы не знали о женщинах в белорусском бизнесе», [электронный ресурс] https://kyky.org/news/issledovanie-vse-chego-vy-ne-znali-o-zhenschinah-v-belaruskom-biznese [дата доступа: 24.06.2020].

Linkedin, https://www.linkedin.com [дата доступа: 22.06.2020]. 
Marta Gavinek-Dagarguliya o tom, kak byt biznesvumen v Polshe, Biznes Razvitie || Mapma Гавинек-Дагаргулия о том, как быть бизнесвумен в Польше, Бизнес Развитие, [электронный ресурс] http://brbel.by/novost-1-2-2-2-2-2 [дата доступа: 11.06.2020].

MIWE2018, [электронный ресурс] https://newsroom.mastercard.com/documents/ mastercard-index-of-women-entrepreneurs-miwe-2018 [дата доступа: 21.06.2020].

Nacionalnyj plan deistvij po obespecheniyu gendernogo ravenstva na 2017-2020 gg. Utverzhden Postanovleniem Soveta Ministrov Respubliki Belarus ot 17 fevralya 2017 g. No. 149 || Национальный план действий по обеспечению гендерного равенства на 2017-2020 гг. Утвержден Постановлением Совета Министров Республики Беларусь от 17 февраля 2017 г. № 149, [электронный ресурс] http://www.mintrud.gov.by/system/extensions/spaw/uploads/files/Nats-plan. pdf [дата доступа: 24.06.2020].

O razvitii agroekoturizma: Ukaz Prezidenta Respubliki Belarus ot 9 oktyabrya 2017 g. No. 365 || О развитии агроэкотуризма: Указ Президента Республики Беларусь от 9 октября 2017 г. № 365, [электронный ресурс] https://pravo.by [дата доступа: 21.06.2020].

O razvitii predprinimatelstva: Dekret Prezidenta Respubliki Belarus ot 23 noyabrya 2017 g. No. 7 || О развитии предпринимательства: Декрет Президента Республики Беларусь от 23 ноября 2017 г. № 7, [электронный ресурс] http:// president.gov.by [дата доступа: 21.06.2020].

O regulirovanii deyatelnosti fizicheskikh lic: Ukaz Prezidenta Respubliki Belarus ot 19 sentyabrya 2017 g. N. 337 || О регулировании деятельности физических лиц: Указ Президента Республики Беларусь от 19 сентября 2017 г. № 337.

Ob osushchestvlenii fizicheskimi licami remeslennoj deyatelnosti: Ukaz Prezidenta Respubliki Belarus ot 9 oktyabrya 2017 g. o. 364 || Об осуществлении физическими лицами ремесленной деятельности: Указ Президента Республики Беларусь от 9 октября 2017 г. № 364, [электронный ресурс] http://president. gov.by [дата доступа 21.06.2020].

Oficialnyj sajt Ministerstva ekonomiki Respubliki Belarus || Официальный сайт Министерства экономики Республики Беларусь, [электронный ресурс] http:// economy.gov.by/ru/remeslo-ru [дата доступа: 22.06.2020].

Oficialnyj sajt OAO «Belinvestbank» || Официальный сайт ОАО «Белинвестбанк», [электронный ресурс] https://www.belinvestbank.by/business/page/ biznes-obuchenie [дата доступа: 29.06.2020].

Predstavitelstvo obshchestvenno poleznogo obshchestva s ogranichennoj otvetstvennostyu "Internationales Bildungs und Begegnungswerk gemeinnützige Gesellschaft mit beschränkter Haftung” (Federativnaya Respublika Germaniya) v Respublike Belarus || Представительство общественно полезного общества с ограниченной ответственностью «Internationales Bildungs und Begegnungswerk gemeinnützige Gesellschaft mit beschränkter Haftung» (Федеративная Республика Германия) в Республике Беларусь, [электронный ресурс] http://ibb-d.by/2019/12/03/ 
zhenskij-biznes-v-belarusi-prezentatsiya-rezultatov-issledovaniya-ifc-i-beroc [дата доступа: 24.06.2020].

"Proekt stoit". Esli selskii biznes-inkubator ne zarabotaet, $1 \mathrm{mln}$ dollarov pridecya vernut ES, tut.by, 16.02.2016 || «Проект стоит». Если сельский бизнес-инкубатор не заработает, 1 млн долларов придется вернуть EC, tut.by, 16.02.2016, [электронный ресурс] https://news.tut.by/society/485051.html [дата доступа: 22.06.2020].

Press-relizy || Пресс-релизы, [электронный ресурс] https://newsroom.mastercard. com/ru/press-releases [дата доступа: 11.06.2020].

Respublikanskaya konfederaciya predprinimatelstva || Республиканская конфедерация предпринимательства, [электронный ресурс] https://rce.by/articles/ article3.php [дата доступа: 11.06.2020].

Reznik S.D., Makarova S.N., 2009, Gendernyj menedzhment: zhenshchiny $v$ upravlenii: ucheb. posobie, Moskva || Резник С.Д., Макарова С.Н., 2009, Гендерный менеджмент: женщины в управлении: учеб. пособие, Москва. 